\title{
宇宙ロボットの遠隔操作カ制御システム
}

\author{
内 山 勝* 金田悟** 北垣 高 成***
}

\section{A Teleoperated Force Control System for Space Robots}

\author{
Masaru UCHIYAMA Satoru KANEDA Kosei KITAGAKI
}

For the teleoperation of force controlled space robots in orbit by a human operator on the ground, communication time delay becomes a difficult problem. In this paper, to solve this problem, a new teleoperation control scheme is proposed. In this scheme, the robot has two control modes : velocity and force control modes, either of which is selected automatically according to contact conditions between the robot and its environments. The coefficient that converts the force command into the velocity command is decided based on the analysis of the optimal approach velocity. Since the both control modes are implemented by an on-board computer in orbit, no force reflection to the human operator is needed even in the force control mode. Moreover, to aid the operator's $3 \mathrm{D}$ visual perception, it is proposed to use a virtual beam which is generated by a ground computer using a geometrical model. With this aid, operation in the velocity control mode is improved.

Key Words : Space Robot, Teleoperation, Force Control, Autonomous Control, Computer Aided Vision

\section{1. は じめに}

宇宙での活動は安全性の点から，ロボットに行わせる ことが望ましいが，現在の技術では，要求される作業を ロボットが完全に自律的に行うことは困難なため, 遠隔 操作により人間とロボットを協力させ，互いに他を補い ながら作業を行ら必要がある. しかし, 地上の人間と軌 道上のロボットの間の通信には, 容量の制限や片道約 2 秒といわれる通信時間の遅れがあるため，オペレータと ロボットの協力の奶げとなる ${ }^{1)}$.

この問題に対処するため, ロボットがオペレータに代 わって部分的に指令を計画する機能2)，ロボットとその 作業環境の情報を推测し，オペレータに提示する機能 ${ }^{3)}$ などが考えられている．また，推定された情報を実画像 に重沿合わせて表示する手法も提案されている4). 一般 に，遠隔操作システムを設計するとき，具体的にどのよ

原稿受付 1991 年 4 月 3 日

* 東北大学工学部 $* *$ 日本電気株式会社

*** 電子技術総合研究所
うな機能をシステムに持たせるべきかは, 要求される作 業に依存する.

マニピュレータが環境中の対象物に接触して実行され る作業では, この接触動作の安全, 確実性が必要で, こ のため, 遠隔操作マニピュレータに力制御機能が必要と なる ${ }^{5)}$. 本論文では，この接触動作に注目し，これを円 滑に行うための新しい力制御方式を提案する.すなわち, 筆者らがすでに提案している最適接近速度の考え方 ${ }^{6}$ を 接触動作の制御に適用し，速度と力の切り替えを円滑に 行う部分自律機能を夷現する ${ }^{7), 8)}$.

このシステムでは，オペレータに作業中の反力を直接 フィードバックしないため, オペレータはマニピュレー タや外部環境に関する 3 次元位置情報を視覚から取得す る必要がある。一般に， 3 次元位置情報の取得法として は, 両眼による方法が研究, 開発されているが（例えば, 文献 9)), 宇宙遠隔操作システムでは，先に述べた通信 容量の制約により，両眼の画像を直接利用することは困 難であると考えられる，そこで，本研究では，単眼によ る立体視の効果を積極的に利用する方法を新たに提案す 
る.これは，仮想的な光ビームをシミュレーションによ り生成し， 2 次元画像上に表示することにより，立体視 の補助とするものである.

以上の考え方により，マニピュレータの遠隔操作シス テムを構成し，通信時間に遅れのある設定で作業実験を 行い, その有効性を検証する.

\section{2. 最適接近速度を考虑した遠隔操作 カ制御システム}

むだ時間を含まない遠隔操作システムでは,マニピュ レータと外部環境の間の接触力をオペレータにフィード バックすることにより操作性を高めることができる ${ }^{10)}$.

しかし, 通信時間に遅れがある場合, このようなフィー ドバックはシステムの安定性を損ならため, 結果的にシ ステムの応答速度を犠牲にする. しかし，接触動作に伴 って発生する衝撃力の制御には即応性が求められるため, このような応答速度の低下は, システムの性能を劣化さ せ, 望ましくない.この解決法として, 即応性を必要と する接触力の制御機能をロボット側に自律機能として実 現する方法が考えられる.

\section{1 速隔操作力制御システム}

システムのブロック線図を Fig. 1 に示す. オペレー タは, 力覚センサを内蔵したジョイスティックを用いて 力またはモーメント $f_{r}$ を指令として入力し, マニピュ レータを操作する，通信時間に遅れがあるため, マニピ

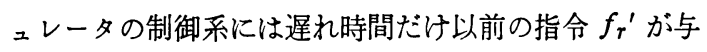
えられる. マニピュレータは手首に力覚センサを装着し,
接触力またはモーメント $f_{s}^{\prime}$ を検出する. 指令 $f_{r}^{\prime}$ を受 けた制御系は， $f_{s}^{\prime}$ をフィードバックし、マニピュレー タをローカルに力制御する。このため, 通信時間遅れの 有無に関わらず，安定な力制御が実現される.なお，本 論文では，ロボットの作業座標を各軸独立に取り扱い, 制御方式を定式化する. したがって，ここで取り扱う $f_{r}, f_{r}{ }^{\prime}$ などはすべてスカラである. 以下同様とする.

オペレータには $f_{s}^{\prime}$ は直接にはフィードバックされ ない. オペレータにフィードバックされる情報は，TV カメラにより検出された視覚情報である. TV カメラに より検出された情報 $S^{\prime}$ は，時間遅れを経て $S^{\prime \prime}$ となり， ディスプレイによりオペレータに提示される. オペレー タは, ディスプレイの映像により視覚的に作業環境を認 識し, 指令を計画する.オペレータが視覚情報を処理し, 動作を計画する時間周期は, 力制御の時間周期よりも長 いため, 通信時間遅れの影響は軽減される.

マニピュレータの制御系のブロック線図を Fig. 2 に 示す. マニピュレータは以下に示す 2 つの制御モードを 持ち, エンドェフェクタが外部環境と接触しているかい ないかを各軸（並進と回転の6 軸）ごとに判断し, 自律 的に制御モードを切り替え, オペレータからの指令 $f_{r}$ に従って動作する. 接触の判断は, その方向の力または モーメントが設定されたしきい值を越えたかどうかによ り行 5 .

速度制御モード（非接触モード）：エンドェフェクタ と外部環境が接触していないときの制御モードで， $f_{r}$ に ゲイン $k_{a}$ をかけた速度または角速度 $v_{r}$ を目標值とし

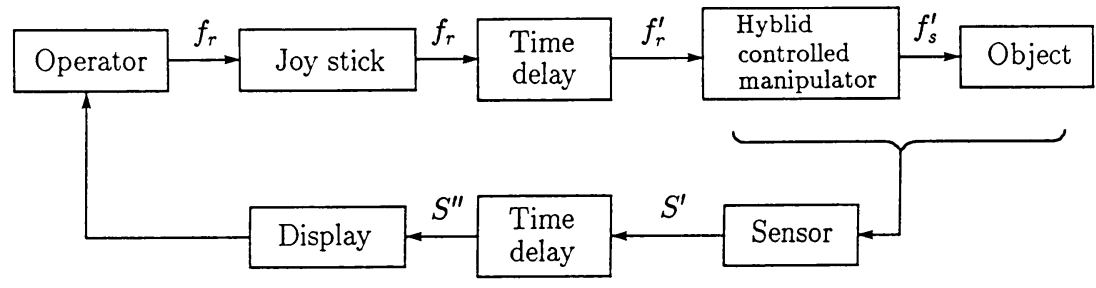

Fig. 1 A block diagram of a teleoperation system

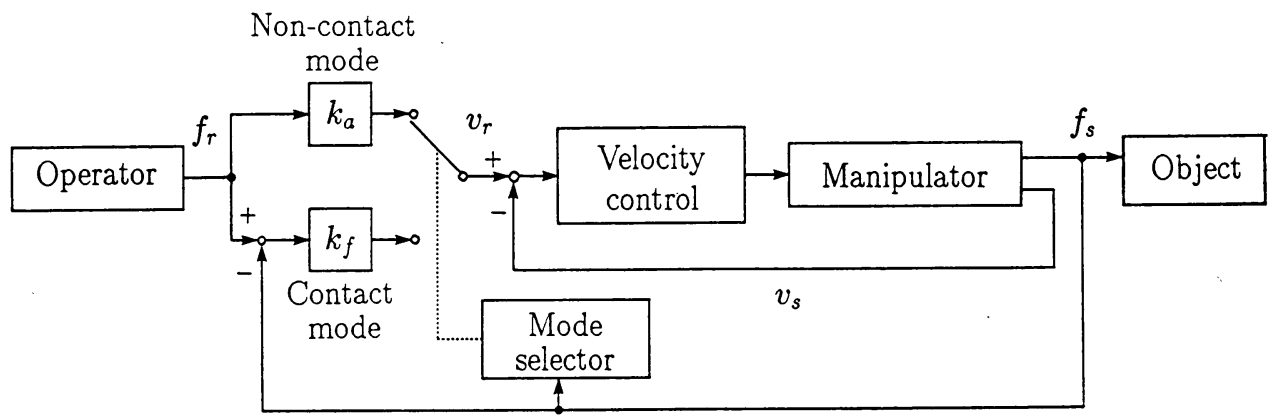

Fig. 2 A block diagram of a hybrid velocity/force servo 
て，速度制御される.すなわち，

$$
v_{r}=k_{a} f_{r}
$$

カ制御モード（接触モード）:エンドェフェクタと外 部環境が接触しているときの制御モードで， $f_{r}$ を力制 御の目標值とする.すなわち, 速度指令 $v_{r}$ を次式によ り計算する. $k_{f}$ は力フィードバックゲインである.

$$
v_{r}=k_{f}\left(f_{r}-f_{s}\right)
$$

ゲイン $k_{f}$ と $k_{a}$ によって, 遠隔操作システムの接触 動作の特性が決定する. 以下，その決定法について述べ る.

\section{2 最適接近速度}

接触にともなって生じる衝撃力は，マニピュレータの 接近速度, 質量, 対象物体の剛性などの接触条件, およ び接触後に行われる衝撃力の抑制制御に依存して決まる。 これに対して, 筆者らは, マニピュレータの接近速度に 注目し, 対象物体の特性に依存する最適な接近速度を選 ぶことで, 接触後の力制御の立上りを速くし, かつ接触 の衝撃力を低く抑える方法を提案している ${ }^{6)}$. ここでは， この方法により $k_{a}$ を決定する.

まず, 接触後の力制御系に注目し, 接触力 $f_{s}$ とその 平衡値 $f_{0}$ の 2 乗偏差

$$
J=\int_{0}^{\infty}\left(f_{s}-f_{0}\right)^{2} d t
$$

を評価指標とする．力制御系は接近速度 $v$ を初期条件と して含むから, 他の条件が一定のとき，このJを最小に する $v$ が存在する. これを最適接近速度 $v_{o p t}$ とする.

マニピュレータと外部環境の接触を接触方向について の 1 次元のばね, 質量, ダンパ系と考え, さらに, 目標 接触力 $f_{r}$ が一定で, 接触後の力制御が $\mathrm{P}$ 制御と仮定し, この最適化問題を解くと, 最適接近速度 $v_{o p t}$ がつぎの ように求められる ${ }^{6)}$.

$$
v_{o p t}=k_{a} f_{r}
$$

ここで

$$
k_{a}=\frac{k_{v} k_{f}\left\{c\left(1+k_{f} k_{v}\right)+k_{v}\right\}}{\left(1+k_{v} k_{f}\right)\left\{c^{2}\left(1+k_{v} k_{f}\right)+k m\right\}}
$$

である. $m$ はマニピュレータの有効質量, $k, c$ はそれぞ れマニピュレータと外部環境の合成ば称係数, 合成粘性 係数である. また， $k_{v}$ は力制御ループ内にある速度サ 一ボのフィードバックゲインである.

(4) 式により, 最適接近速度 $v_{o p t}$ は目標接触力 $f_{r}$ に比例することがわかる.この比例係数 $k_{a}$ を接触が起 こりらる外部環境の特性データとして, あらかじめ用意 しておき，ある外部環境に接触するとき，この $k_{a}$ と接 触力の目標値 $f_{r}$ から, 最適接近速度 $v_{o p t}$ を決定する. 本研究の遠隔操作システムでは, マニピュレータを外部 環境に接触させようとするとき，オペレータは目標接触

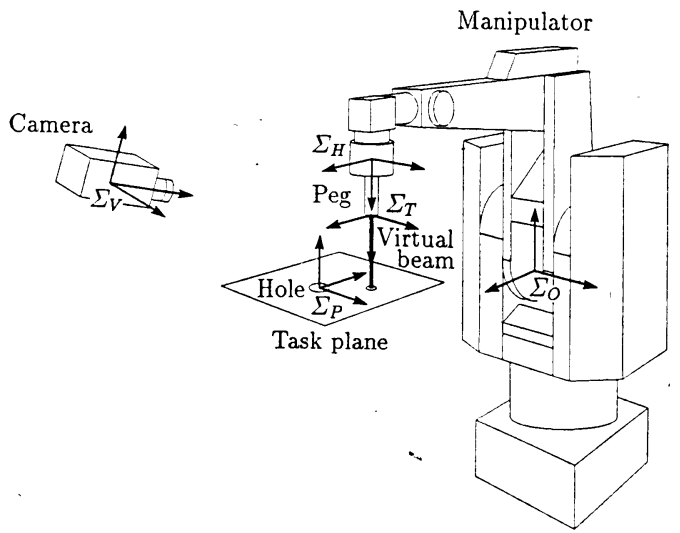

Fig.3 A geometrical model of a robot and its environments

力 $f_{r}$ を入力し, 接近動作を行う. したがって,（1)式 の $k_{a}$ を（5）式により決定すれば最適接近動作が実現 される。

\section{3 次元位䕎情報の提示}

\subsection{2 次元画像による立体視}

ロボットの遠隔操作では, オペレータはマニピュレー タと作業対象, あるいはマニピュレータが操作するッー ルと作業対象との 3 次元相対位置関係を知る必要がある. 本システムでは, オペレータはこの情報を 1 台の TV カメラによる視覚, すなわち単眼視により取得する.人 間は, 単眼でも陰や物体の重なり具合いなどから，3 次 元位置情報を取得する能力を備えている. しかし，一般 に, 影を作るには照明が必要であり, また, 重なり具合 いで位置関係を知るためには，基準となる物体が必要で ある.これらの条件を最適に設定することは，一般に難 しい.

そこで, 本研究では, これらの条件を地上のコンピュ ータのシミュレーションにより生成し，オペレータを支 援する方法を提案する. すなわち，マニピュレータが操 作するッール先端から仮想的な光ビームを照射し, 対象 面にそのスポットを作る.オペレータは，このビームの 長さや方向, スポットの位置を見ることにより, 幾何的 な類推から、ツールと作業対象との相対的な位置関係を 認識する. シミュレーションの世界では, 作業に都合の 良いビームを生成できるので，これを実画像にスーパー インポーズすれば，柔軟性に富むオペレータ支援が実現 できる。

本論文では，このビームを仮想ビームと呼ぶ．以下， 本研究で用いた仮想ビーム生成のための幾何学モデルと その処理について述べる。 


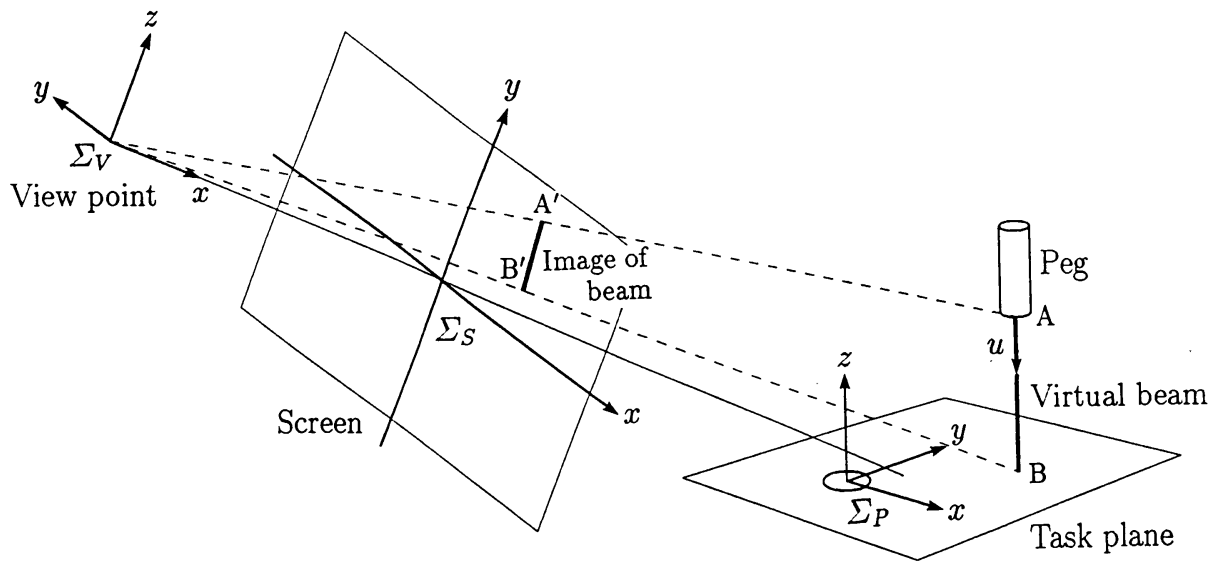

Fig. 4 Perspective transformation of a virtual beam

\section{2 仮想ビーム生成のための幾何学モテル}

ここでは, 仮想ビームの生成に用いるシミュレーショ ンの世界の物体として， Fig. 3 に示すマニピュレータ， エンドェフェクタ, ツール, 作業面, および視点となる カメラを考える. 各物体の位固, 姿勢を記述するために, これらの物体に以下の座標系を固定する.

\section{$\Sigma_{0}:$ 基準座標系}

$\Sigma_{H}:$ エンドェフェクタ座標系

$\Sigma_{T}:$ ツール座標系

$\Sigma_{P}:$ 作業面座標系

$\Sigma_{V}:$ 視点座標系

基準座標系 $\Sigma_{0}$ はマニピュレータのリンク0の座標系 にとる. エンドェフェクタ座標系 $\Sigma_{H}$ はマニピュレータ のエンドェフェクタに固定した座標系である. その位直, 姿勢は, マニピュレータの関節角度より計算できる.ツ 一ル座標系 $\Sigma_{T}$ は土ンドェフェクタで把持した対象物に
固定した座標系で，その原点はその対象物に対する作業 の代表点とする．例えば，ピンを挿入する作業では， Fig. 3 のようにピンの先端を原点とし，ピン挿入作業の 対称性からピンの軸方向に座標軸をとる. $\Sigma_{T}$ の $\Sigma_{H}$ に 対する位置, 姿勢は, 把持した対象物の形状とその把持 状態によって定まる．これは何らかの手段によって既知 であるとする．作業面座標系 $\Sigma_{P}$ は，作業対象となる環 境中の物体の代表面を $x y$ 平面とし, その中心を原点, 法線方向を $\boldsymbol{z}$ 軸とする座標系である. 作業対象の位置, 姿勢は，基準座標系 $\Sigma_{0}$ に対して既知であると考える. 視点座標系 $\Sigma_{V}$ は, 視点の位置を原点とし, 視線の方向 を $x$ 軸とする座標系で, 同様に， $\Sigma_{0}$ に対して，その位 置, 姿勢は既知であると考える.

これらの座標系の間の位置, 姿勢の関係の記述には, 同次変換行列を用いる.

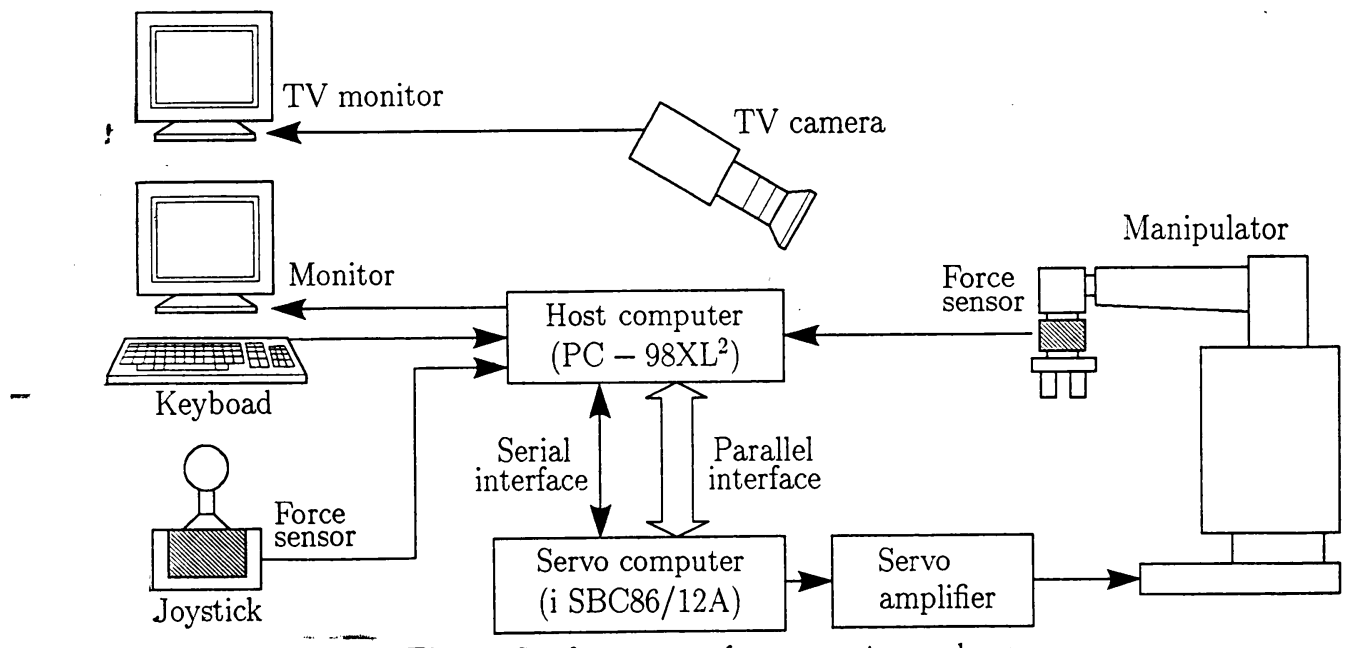

Fig.5 Configuration of an experimental setup 


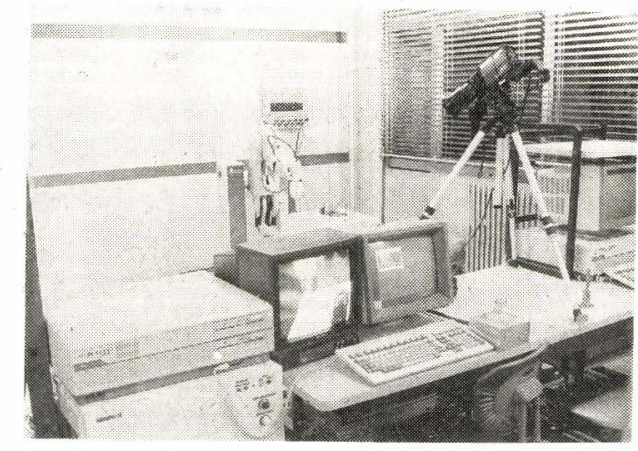

Fig.6 A photograph of an experimental setup

\section{3 仮想ビームの生成}

仮想ビームを生成する場合，まず，その発生点と方向 を指定する必要がある. ビームの発生点の位置べクトル を $\boldsymbol{x}_{A}$, ビームの方向を $\boldsymbol{u}$ とすると, ビームの方程式は

$$
\boldsymbol{x}=\boldsymbol{x}_{A}+s \boldsymbol{u}
$$

となる， $\boldsymbol{x}$ はビーム上の点の位置べクトル， $s$ はパラメ ータである.

つぎに, 仮想ビームと作業面の交点, すなおら, 作業 面上でのスポットの位置を表すべクトル $\boldsymbol{x}_{B}$ を求める. スポットは作業面座標系 $\Sigma_{P}$ の $x y$ 平面上にあるから, $\Sigma_{P}$ で成分表示した $\boldsymbol{x}_{B}$ の $\boldsymbol{z}$ 座標は0である， $\Sigma_{P}$ で成 分表示した $\boldsymbol{x}_{B}$ を ${ }^{{ }^{P}} \boldsymbol{x}_{B}$ とすると

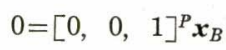

となる。一方，（6）式を $\Sigma_{P}$ で成分表示すると

$$
{ }^{P} \boldsymbol{x}={ }^{P} \boldsymbol{x}_{A}+s^{P} \boldsymbol{u}
$$

となる. ${ }^{P} \boldsymbol{x}_{B}$ は (8) 式上の点であるから, (8) 式の ${ }^{P} \boldsymbol{x}$ を (7) 式の ${ }^{P} \boldsymbol{x}_{B}$ に代入し, $s$ について解くと, ス ポット上の $s$ か

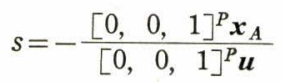

と求められる. これを（6）式に代入すると $\boldsymbol{x}_{B}$ を得る. すなおら

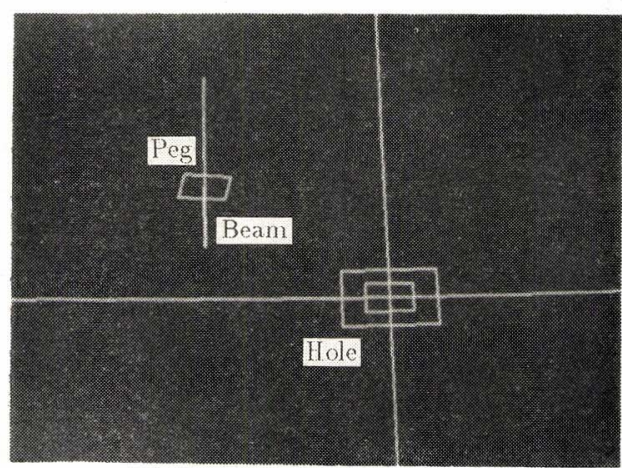

Fig. 8 An image of a virtual beam

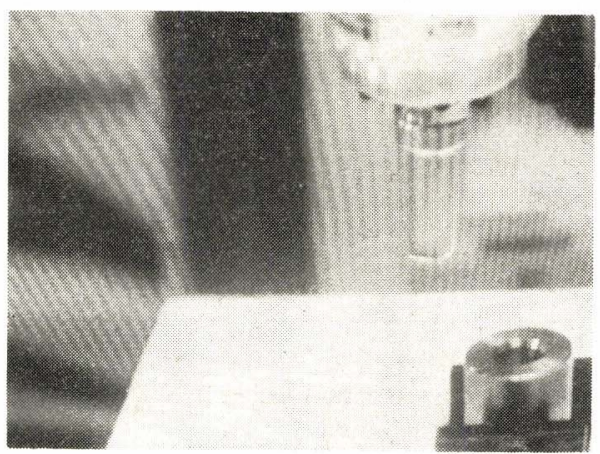

Fig.7 A TV image of a teleoperated task

$$
\boldsymbol{x}_{B}=\boldsymbol{x}_{A}-\frac{[0,0,1}{\left[\begin{array}{ll}
P & \boldsymbol{x}_{A} \\
{[0,0,} & 1
\end{array}\right]^{P} \boldsymbol{u}} \boldsymbol{u}
$$

ビームの発生点と作業面上のスポットを透視変換し, 結果を画面上で結べば, 仮想ビームの像が得られる.こ の様子を Fig. 4 に示す. 透視変換の視点, すなわち, カメラの位置, 姿勢が与えられれば, その画面内のビー ムの位置, 姿勢は容易に計算される.

\section{4. 実験システム}

\section{1 構成}

実験システムの構成を Fig. 5 に, 全景を Fig. 6 に 示す. 本システムは著者らが開発した研究用ロボットシ ステム $\mathrm{ARS} / \mathrm{A}^{11)}$ 上に実現されている. システムの統括 は 32 ビットのホストコンピュータにより行われる・マ ニピュレータは 16 ビットのサーボュンピュータにより 制御される.マニピュレータとしては， 6 軸の多関節型 産業用ロボットを用いている. その手首部には力制御の ための 6 軸力覚センサが装着されている. ジョイスティ ックには同様な 6 軸力覚センサを用いている. その信号 は $\mathrm{A} / \mathrm{D}$ 変換器からホストコンピュータに入力される. オペレータへの視覚フィードバックはTVカメラにより 行う. カメラの視点は固定とする.オペレータのコンソ ール部とマニピュレータの間には遮蔽板が置かれ, 両者 は分離される.

遠隔操作システムは, Fig. 1 のシステムをもとに構成 する．仮想ビームの計算に必要なマニピュレータの関節 角度は, 軌道上より送られてくるデータを用いる. ディ

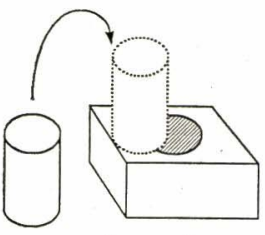

Approach

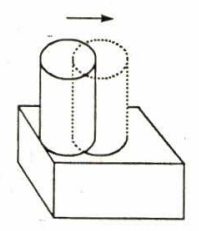

Search

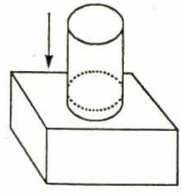

Insertion
Fig.9 A peg-in-hole task 


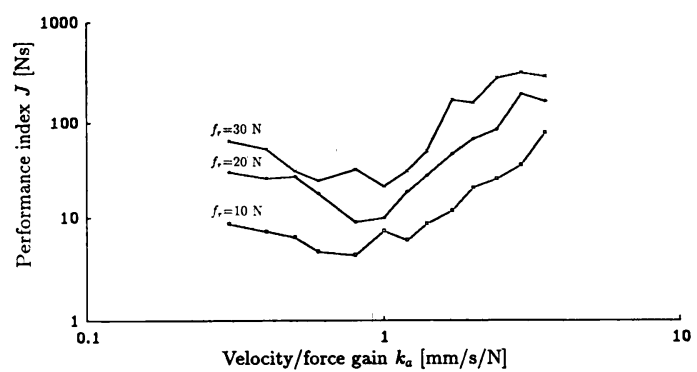

Fig. 10 Performance index $J$ vs. velocity/ force gain $k_{a}$

スプレイ上に表示された視覚情報をもとに，オペレータ は, ジョイスティックにより指令を入力し，送信する. なお, ジョイスティックの力とモーメントの分離は難し いため, キーボードにより力またはモーメントを指定し, 各瞬間には 3 軸の力またはモーメントを送信する．選択 されない力またはモーメントの指令は０とする.

本実験では，ハードウェアの制約により仮想ビームを 実画面に重ねて表示できない，そこで，仮想ビームは別 画面に表示し，オペレータは実画面と仮想ビーム画面を 同時に見ながら 3 次元位置関係を認識する．実画面の例 を Fig. 7 に，そのときの仮想ビーム画面を Fig. 8 に 示す.なお，実画面を生成するカメラの位置，姿勢と仮 想ビーム画面を生成するカメラの位置, 姿勢は, 両画面 内のマニピュレータの動きがオペレータにとって一致す

\section{るように設定する.}

\section{2 通信時間遅れのシミュレート}

地上と軌道上の間の通信時間遅れを $T$ とすると, マニ

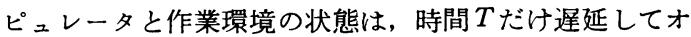
ペレータに届く.それを受けたオペレータからの指令は,

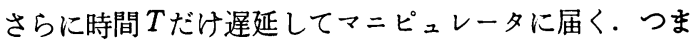
り, 一方の側がある状態を取ってから, それに対するも ら一方の側からの反応が戻ってくるまでに合計 $2 T$ の時 間がかかる. 本研究では, オペレータとロボットの間に 形成されるフィードバックループの挙動を問題としてい る. したがって，行きと戻りのそれぞれの遅れがどのよ らな值でも，合計が $2 T$ なら，結果は同じであると考え る. そこで, 本実験では, 通信時間遅れ $T$ を情報量の少 ない操作指令の遅れに集約し，これを $2 T$ とし，画像伝 送の遅れて 0 とする。

\section{5. 実験}

\section{1 対象作業}

対象作業としてピン挿入作業を選ぶ.この作業は, Fig. 9 に示すように，以下の 3 つの作業要素により構成 される。

Approach：ピンを初期位置からホール近くまで移動 させる作業

Search : ピンをホール近くに接触させながら, ホ ールまで滑らせる作業

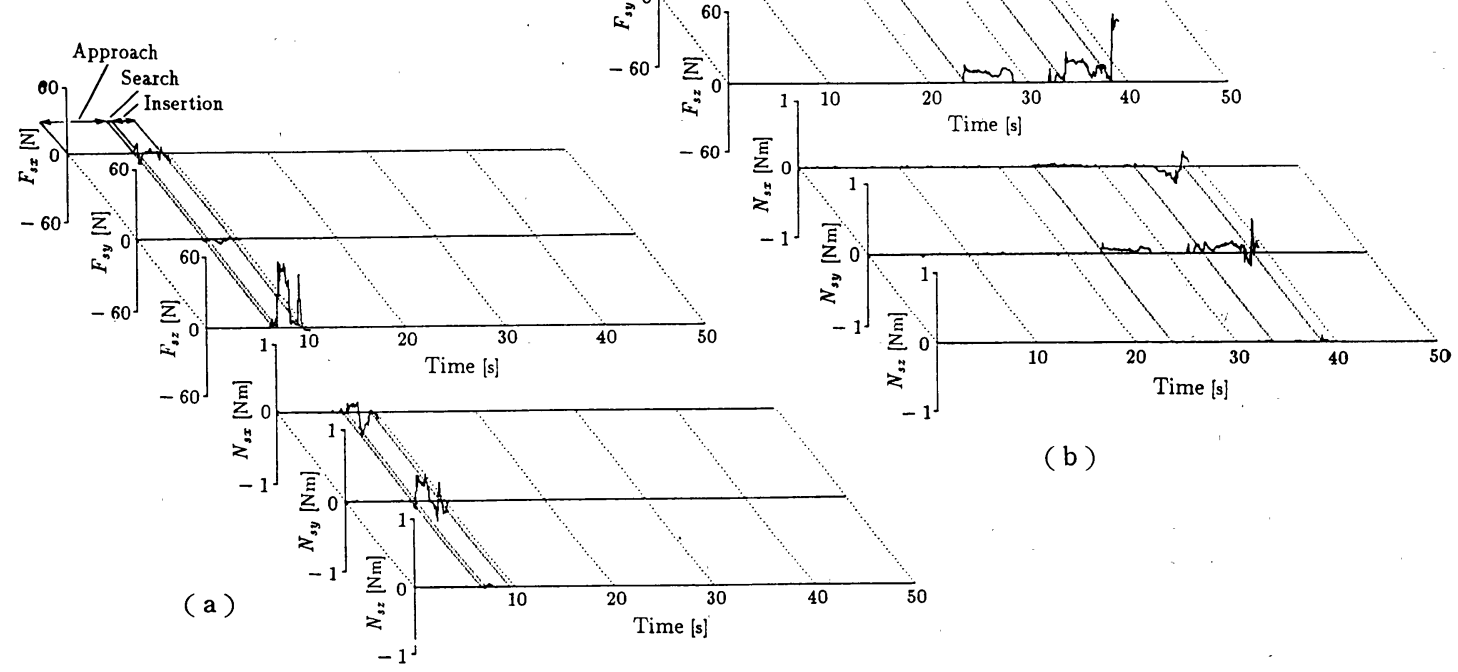

Fig. 11 Examples of contact forces and moments (without a virtual beam)

(a) Communication delay $=0.0 \mathrm{~s}$, (b) Communication delay $=2.5 \mathrm{~s}$. 


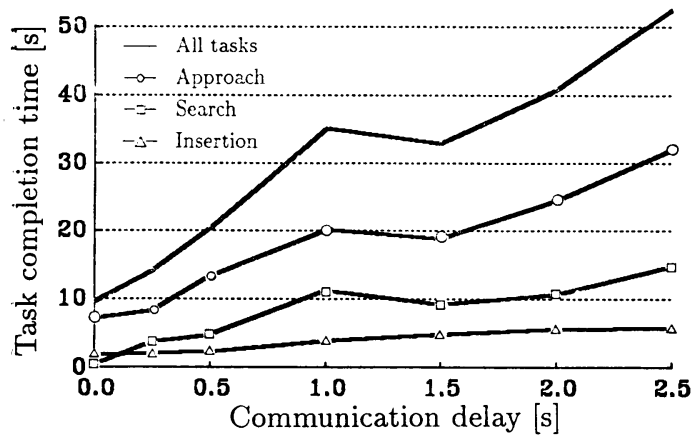

Fig. 12 Task completion time vs. communication delay (without a virtual beam)

Insertion : ピンをホールに挿入する作業 Approach は視覚フィードバックを伴う無拘束移動, Search は視覚フィードバックを伴う拘束移動, Insertion は視覚フィードバックを伴わない拘束移動である. このようにこの作業はそれぞれ性格の異なる基本的な 作業要素により成り立っているため, 遠隔操作システム の特性分析に適している.

実験で使用したピンの直径は $20 \mathrm{~mm}$ ，長さは $50 \mathrm{~mm}$ である.これに対するホールのすきま比は $1 \%$ である. 実験の再現性を高めるため, ピンはハンドにより把持す るのではなく, 手首の力覚センサの先に固定する.

本実験におけるオペレータ指令は, Fig. 3 の基準座標 系 $\Sigma_{O}$ で成分表示される. $\Sigma_{O}$ の $z$ 軸は $\Sigma_{P}$ の $z$ 軸に平 行である.なお，この設定はあくまで便宜上のもので, 作業内容により容易に変更できる.

\section{2 最適接近速度の測定}

本論文の遠隔操作システムでは, 作業に必要な知識と して, 最適接近速度を求める変換係数 $k_{a}$ が必要である. ここでは, 実験によりこの係数を決定する.

まず, カフィードバックゲイン $f_{r}$ を力制御が安定に 行えるように定め, そのゲインを用いたシステムに対し て,（3）式の評価指標 $J$ が最小となるように $k_{a}$ を決 定する.ここでは，ピンをホール近傍の作業面に垂直方 向から接触させる実験を行い $k_{a}$ を決定する. 与えられ た目標接触力 $f_{r}$ に対して, 変換係数 $k_{a}$ を変えながら接 触実験を行い, そのときの接触力と平衡力を測定し, 数 值積分によりJを計算する.そして，この值が最小とな るように $k_{a}$ を決定する.

実験結果をFig. 10 に示す. 本実験では, 力制御ゲイ ンは $k_{f}=1.3 \mathrm{~mm} / \mathrm{s} / \mathrm{N}$ とした. いくつかの異なる目標 接触力 $f_{r}$ について実験を行ったが， $J$ を最小にする $k_{a}$ は， $f_{r}$ によらないことがわかった.この結果から， $k_{a}$ $=1.0 \mathrm{~mm} / \mathrm{s} / \mathrm{N}$ とした.

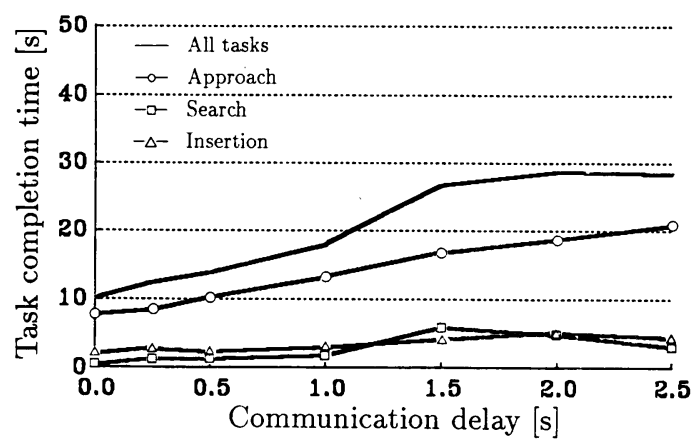

Fig. 13 Task completion time vs. communication delay (with a virtual beam)

\section{3 仮想ビームによる支援なしの作業実験}

視覚情報としてTVカメラ画像のみを用いて夷験を行 った. 実験は, $0.0 \mathrm{~s} \sim 2.5 \mathrm{~s}$ の間の 7 種類の通信時間遅 れについて, 各 5 回繰り返し作業を行うもので,この実 験を 3 人の被検者について各 2 回行った. 最初の 1 回を 練習とし，2回目のデータを本データとした．なお，接 触の判断のためのしきい值は, 各軸共通とし, 力につい ては $1 \mathrm{~N}$ ，モーメントについては $0.1 \mathrm{Nm}$ とした。

本実験では, オペレータは, まずピンをホール作業面 上方に位置決めし，つぎにピンをホール作業面に接触さ せる動作に移る.こうすることにより, オペレータは, ピンの作業面への押し付け力を意識してジョイスティッ クに指令を与えることができ，ホール作業面への最適接 近速度が実現される。

作業性の評価は, 過去に行われたピン挿入作業の研 究 $^{12)}$ にならい, 接触力および作業時間の評価により行っ た. 各評価結果は同様な傾向を示した.

一例として, ある被検者の 2 回目の実験で, 通信時間 遅れがそれぞれ， $0.0 \mathrm{~s}, 2.5 \mathrm{~s}$ の場合の接触力の測定結 果を Fig. 11 に示す. 図にはピンに作用した各軸方向の 接触力を示している. 接触力は基準座標系 $\Sigma_{O}$ で成分表 示している. $F_{s x}, F_{s y}, F_{s z}$ は接触力の $x, y, z$ 成分, $N_{s x}, N_{s y}, N_{s z}$ は接触モーメントの $x, y, z$ 成分である. 横軸には, Approach, Search, Insertionの各作業要素 の推移も示している. この実験結果より, 接触力の大き さが通信時間遅れの有無に影響を受けないことがわかる. これは, 接触力の制御がロボットの側で自律的に行われ ていることの効果を示すものといえる.

また，作業時間による評価は，通信時間遅れ（communication delay) に対する各作業要素の 5 回の平均作 業時間 (task completion time) を求めることにより行 った. Fig. 12 にある被検者の 2 回目の実験結果を示す. 通信時間遅れに対して全作業時間が直線的に増大してい ることがわかる. 通信時間遅れが $2.5 \mathrm{~s}$ のときの全作業 
時間は $53 \mathrm{~s}$ である。しかし，その增加を各作業要素につ いて見ると，視覚フィードバックに依存する Approach とSearch に怙いて著しいことがわかる. 視覚フィード バックによらないInsertion では作業時間の著しい增加 は見られない.これは，力制御をロボット側で自律的に 行っていることの効果を示すものである.

\section{4 仮想ビームによる支援ありの作業実験}

前節と同様の条件で，仮想ビーム画面を TVカメラ画 像と併用した実験を行った．実験は， $0.0 \mathrm{~s} \sim 2.5 \mathrm{~s}$ の間 の 7 種類の通信時間遅れについて, 各 5 回繰り返し行う もので, これを 3 人の被検者について各 3 回行った。最 初の 1 回を練習とし, 残りの 2 回を本データとした.

実験の評価は前節と同様に行った．各評価結果は同様 な傾向を示した.

その一例として，ある被検者の 3 回目の実験の作業時 間による評価結果を Fig.13 に示す.この結果から, TV カメラ画像のみのときと同様, 通信時間遅れに対して作 業時間が直線的に增大していることがわかるが，その増 大の傾きは小さく，通信時間遅れが $2.5 \mathrm{~s}$ のときでも全 作業時間は $28 \mathrm{~s}$ に収まっている。これより，仮想ビー ムによる支援画像の有効性が確認される.

なお，Search において時間遅れの影響がほとんどな く, 作業が短時間で完了しているのは, 仮想ビームの支 援により, Approach の終了時点において，ピンがホー ルに対して Searchの必要がほとんどないほど高精度に 位置決めされるためである。また，Approach において， 仮想ビームの支援による効果が時間遅れが大きいほど大 きくなっているのは, 時間遅れが小さいときには, オペ レータはジョイスティックの指令に応答するピンの動き を見て, これよりピンとホールの位置関係を想像し, 空 間感覚を取得できるためであると考えられる. 時間遅れ が大きくなると, オペレータのこの能力は劣化し, 仮想 ビームによる支援が効果を発揮する.

\section{6.おわりに}

軌道上の宇宙ロボットをオペレータが地上より遠隔操 作する場合を想定し，そのとき問題となる通信時間遅れ の問題を克服するための新しい遠隔操作力制御システム を提案した. このシステムでは, 最適接近速度の考方方 を適用し, 速度制御モードと力制御モードをマニピュレ 一タと作業環境の接触状態に応じて自動的に切り替える ため, オペレータへのカフィードバックを必要とせず, ロボット側でローカルに力制御が行われる.このため, 通信時間遅れの影響をほとんど受けず，良好な操作性が
確保される.

また，このシステムの視覚フィードバックを補助する 目的で, 仮想ビームといら幾何学モデルによって生成さ れたシミュレーションの世界の光ビームを用いる方法を 提案し, 非接触作業における操作性の向上を実現した.

以上の考方方の有効性を時間遅れをシミュレートした 遠隔操作実験システムにより確認した。

\section{謝辞}

実験にご協力頂いた東北大学大学院学生妻木勇一君な らびに学部学生中里浩幸君（現在大学院学生）に感謝す る.

\section{参考文 献}

1）渡辺一郎，内山 隆，“宇宙実験用テレオペレーションシ ステム”, 日本ロボット学会誌, Vol.7, No.6, pp.759$764,1989$.

2）平井成與，佐藤知正，“極限環境とテレロボット”，日本 ロボット学会誌, Vol7, No.6, pp.739-744, 1989.

3) 山下 忠, 池田 広, 門司竜彦, 加藤了三, “ュンピュ 一タ支援遠隔操作のーシミュレーション実験：操作性向 上の評価”, 日本ロボット学会誌, Vol 8, No.2, pp. 188-196, 1990.

4）松井俊浩，塚本享治，“マルチメディアディスプレイを 用いた統合型遠隔口ボット制御法”，日本ロボット学会 誌, Vol6, No.4, pp. 301-310, 1988.

5) G. Hirzinger, "Robot Learning and Teach-In Based on Sensory Feedback," Robotics Research : The Third International Symposium, The MIT Press, pp. 155-163, 1986.

6) 北垣高成, 内山 勝, “外部環境に対するマニピュレー タの最適接近速度”, 日本ロボット学会誌, Vol 8, No.4, pp. $413-420,1990$.

7) K. Kitagaki and M. Uchiyama, "Generating Appropriate Approach Velocities to the Environment in Robot Teleoperation," Proc. IEEE Int. Workshop on Intelligent Robots and Systems, pp.731-736, 1988.

8) M. Uchiyama and K. Kitagaki, "Teleoperation of a Force Controlled Robot Manipulator Without Force Feedback to a Human Operator," Proc. 2nd European In-Orbit Operations Technology Symposium, pp. 173-179, 1989.

9）舘 暲，荒井裕彦，“テレイグジスタンスにおける視 觉情報提示系の設計と評価”, 日本ロボット学会誌, Vol 7, No.4, pp. 314-326, 1989.

10）藤井澄二, “サーボマニプレータの問題”, 日本機珹学会 誌, Vol 59, No.449, pp. 476-479, 1956.

11）北垣高成, 内山勝, “研究用ロボット制御システム ARS/A," 日本ロボット学会誌, Vol. 7, No.5, pp. 475481, 1989.

12）小沢邦昭，“組立作業における手先の機能に関する基砶 的研究”, 東京工業大学修士学位論文, 1973. 